\title{
CONTENT OF SELECTED HEAVY METALS IN NI-CONTAMINATED SOIL FOLLOWING THE APPLICATION OF HALLOYSITE AND ZEOLITE
}

\author{
Maja Radziemska', Zbigniew Mazur ${ }^{2}$ \\ 1 Warsaw University of Life Sciences-SGGW, Faculty of Civil and Environmental Engineering, Nowoursynowska \\ 159, 02-776 Warsaw, Poland, e-mail: maja_radziemska@sggw.pl \\ 2 University of Warmia and Mazury in Olsztyn, Faculty of Environmental Management and Agriculture, \\ Pl. Łódzki 4, 10-727 Olsztyn, Poland, e-mail: zbigniew.mazur@uwm.edu.pl
}

Received: 2016.04.23 Accepted: 2016.06.01 Published: 2016.07.01

\begin{abstract}
Nickel has been listed as a priory control pollutant by the United States Environmental Protection Agency (US EPA). Compared with other methods, the combination of vegetation and the addition of mineral sorbents to heavy metal-contaminated soils can be readily applied on a large scale because of the simplicity of technology and low cost. Halloysite and zeolite, among others, can be used for this purpose. A greenhouse study was performed to evaluate the feasibility of using natural zeolite, as well as raw and modified halloysite for the remediation of simulated Ni-contaminated soil. The soil was spiked with five doses of nickel, i.e. 0 (control), 80, 160, 240 and $320 \mathrm{mg} \cdot \mathrm{Ni} \mathrm{kg}^{-1}$. soil. The average accumulation of heavy metals in nickelcontaminated soil was found to follow the decreasing order of $\mathrm{Ni}>\mathrm{Zn}>\mathrm{Cr}>\mathrm{Cu}>\mathrm{Pb}$. The highest reduction of $\mathrm{Pb}$ content was observed in soil samples taken from pots containing 80 and $160 \mathrm{mg} \cdot \mathrm{kg}^{-1}$ of $\mathrm{Ni}$ along with the addition of modified halloysite. The strongest effects were caused by natural zeolite, which significantly reduced the average content of chromium. Contamination at $320 \mathrm{mg} \mathrm{Ni} \cdot \mathrm{kg}^{-1}$ of soil led to the highest increases in the $\mathrm{Ni}, \mathrm{Pb}$ and $\mathrm{Cr}$ contents of soil.
\end{abstract}

Keywords: halloysite, nickel, soil contamination, zeolite.

\section{INTRODUCTION}

Contamination of soils with heavy metals, including nickel, is a major problem for environmental quality throughout the world. Nickel (symbol Ni, atomic weight 58.71 , atomic number 28) has been listed among the priory control pollutants by the United States Environmental Protection Agency [USEPA, 1997], and is Earth's fifth most common element. Soil can be contaminated with nickel through various anthropogenic activities, such as the rapid development of the steel industry, automobile traffic, sewage sludge and waste, mining and the application of fertilizers [Sas et al., 2015, Radziemska et al., 2015, Tuovinen et al., 2016, Gupta et al., 2014]. Other important sources are products of fossil fuel combustion and crude oil prod- ucts. About $61 \%$ of nickel produced worldwide is used to manufacture stainless steel, $17 \%$ has other uses, including the production of batteries, catalysts, and chemicals, $13 \%$ is used for plating, and the remaining $9 \%$ is used in other nickel alloys [Huang et al., 2009].

Understanding the characteristics of nickel contamination in soils and identifying its environmental exposure risk provides important information for making decisions as to the best method of remediating soils contaminated with this heavy metal [Kuziemska et al., 2014]. The application of low cost, environmentally friendly and easily available reactive materials in the removal of heavy metals from polluted environments, e.g. soils [Wyszkowski and Radziemska, 2009], clarifying the air and sewage [Belchinskaja et al., 2009], and protecting groundwater in traffic infra- 
structure [Fronczyk et al., 2014, 2015] has been widely investigated.

Halloysite nanotubes comprise naturally occurring aluminosilicate nanotubes with a $1: 1$ $\mathrm{Al}: \mathrm{Si}$ ratio and stoichiometry of $\mathrm{Al}_{2} \mathrm{Si}_{2} \mathrm{O}_{5}(\mathrm{OH})_{4}$ $\mathrm{nH}_{2} \mathrm{O}$, and are characterized by regular, openended pores, with a bigger pore radius than that of zeolite [Guimarães et al., 2010]. Halloysite has a large range of applications in many fields, such as biotechnology [Cavallaro et al., 2013], water decontamination [Liu et al., 2013], as an adsorbent of heavy metals from nickel polluted soils [Radziemska et al., 2013, 2014], and as a nanofiller for polymers [Dong et al., 2012]. Moreover, the structures of zeolites consist of three-dimensional frameworks of $\mathrm{SiO}_{4}$ and $\mathrm{AlO}_{4}$ tetrahedra, and these minerals are known to be good adsorbents of heavy metals, such as nickel, chromium, lead, cadmium, copper and zinc [Pimraksa et al., 2013]. One of the three halloysite mines is located in the town of Dunino near Legnica (51 ${ }^{\circ} 8^{\prime} 44^{\prime \prime} \mathrm{N}$, $16^{\circ} 4$ '31"E). The "Dunino" halloysite deposit has resources of at least 10-12 million tons, and is characterized by a homogenous content, high clarity and trace amounts of heavy metals.

The application of zeolites in soil remediation is mainly based on their ion-exchange properties. Zeolites can basically lead to the immobilization of heavy metals in one of two ways: by changes in $\mathrm{pH}$ value and cation exchange [Shi et al., 2009]. The increase in alkalinity promotes the sorption of metals via surface complexation processes. Moreover, heavy metal retention may also take place regardless of $\mathrm{pH}$ value, due to the cation exchange in zeolite. The beneficial effects of zeolites are a result of their high porosity and sorption capacity, which, as in our studies, was also confirmed by Silva et al. [Silva et al., 2008].

The aim of the conducted research was to determine the effects of soil contamination with nickel on the content of selected elements in the soil and to examine whether the applied mineral reactive materials (raw halloysite, modified halloysite and natural zeolite) can be effective in decreasing $\mathrm{Ni}, \mathrm{Pb}, \mathrm{Cr}, \mathrm{Zn}$ and $\mathrm{Cu}$ concentration in soils.

\section{MATERIAL AND METHODS}

The impact of adding raw halloysite, modified halloysite and natural zeolite to nickel contaminated soil on the content of selected micronutriens in soil was assessed under the conditions of a pot experiment at a greenhouse fa- cility of the Warmińsko-Mazurski Universtiy in Olsztyn (north-eastern Poland). The experiment was conducted in three repetitions. Non-polluted soils used for plant cultivation were collected at a depth of 0-20 cm from farmland in the vicinity of Olsztyn, Poland.

The experimental soil was tested for its physicochemical and nutritional properties before sowing the seeds. It was found to be slightly acidic, with a $\mathrm{pH}$ of 4.8 , and contained $7.13 \mathrm{~g} \mathrm{~kg}^{-1} \mathrm{C}_{\text {org }}$, $1.04 \mathrm{~g}^{\mathrm{kg}}{ }^{-1} \mathrm{~N}, 21.20 \mathrm{mg} \cdot \mathrm{kg}^{-1} \mathrm{~N}-\mathrm{NH}_{4}^{+}, 9.88 \mathrm{mg} \cdot \mathrm{kg}^{-1}$ $\mathrm{N}-\mathrm{NO}_{3}{ }_{3}^{-}, 46.60 \mathrm{P} \mathrm{mgkg}^{-1}, 8.20 \mathrm{mgkg}^{-1} \mathrm{~K}^{-1}$ and 33.90 $\mathrm{mg} \mathrm{kg}^{-1} \mathrm{Mg}$. Other metals present were Ni (4.05 $\left.\mathrm{mg} \cdot \mathrm{kg}^{-1}\right), \mathrm{Cr}\left(10.90 \mathrm{mg} \cdot \mathrm{kg}^{-1}\right), \mathrm{Cu}\left(8.49 \mathrm{mg} \mathrm{kg}^{-1}\right)$, $\mathrm{Zn}\left(24.20 \mathrm{mg} \mathrm{kg}^{-1}\right)$ and $\mathrm{Pb}\left(5.44 \mathrm{mg} \mathrm{kg}^{-1}\right)$. The grain size structure was that of light loamy sand (fractions in mm: $2.0-0.05 \%-86.6$; 0.002-0.05$11.2 \%$; $<0.002-2.2 \%$ ), and characterized by the following properties: hydrolytic acidity (HAC) $-33.8 \mathrm{mmol}(+) \mathrm{kg}^{-1}$, total exchange bases (TEB) - $62.2 \mathrm{mmol}(+) \mathrm{kg}^{-1}$, cation exchange capacity (CEC) $-95.9 \mathrm{mmol}(+) \cdot \mathrm{kg}^{-1}$ and base saturation (BS) $-64.8 \%$. The soil was air-died, passed through a $1-\mathrm{cm}$ sieve, and then packed in experimental pots (10 kg soil per pot), and were then used for physical and chemical analysis as well as heavy metal concentration.

Doses of nickel in the amount of 0 (control), $80,160,240$ and $320 \mathrm{mg} \mathrm{kg}^{-1}$ of soil were introduced in the form of chemically pure aqueous solutions of nickel sulphate heptahydrate (Ni$\mathrm{SO}_{4} \cdot 7 \mathrm{H}_{2} \mathrm{O}$ ) (Sigma-Aldrich). Maize (Zea mays L.) of the San variety was the plant of choice for the experiment. The plant density was set at 8 plants per pot and was picked following 69 days of vegetation. The plants were watered with distilled water to $60-70 \%$ of the maximum water holding capacity of the soil. In order to ensure the nutritional needs of plants, aqueous mineral fertilizer solutions were applied in the following amounts (in $\mathrm{mg} \mathrm{kg}^{-1}$ of soil): $\mathrm{N}-110$ $\left[\mathrm{CO}\left(\mathrm{NH}_{2}\right)_{2}\right], \mathrm{P}-50\left[\left(\mathrm{NH}_{4}\right)_{2} \mathrm{HPO}_{4}\right], \mathrm{K}-110[\mathrm{KCl}]$, $\mathrm{Mg}-50\left[\mathrm{MgSO}_{4} \cdot 7 \mathrm{H}_{2} \mathrm{O}\right], \mathrm{B}-0.33\left[\mathrm{H}_{3} \mathrm{BO}_{3}\right], \mathrm{Mn}-5$ $\left[\mathrm{MnCl}_{2} \cdot 4 \mathrm{H}_{2} \mathrm{O}\right]$, and $\mathrm{Mo}-5\left[\left(\mathrm{NH}_{4}\right)_{6} \mathrm{Mo}_{7} \mathrm{O}_{24} \cdot 4 \mathrm{H}_{2} \mathrm{O}\right]$.

Natural zeolite with phase composition of quartz $69.43 \%$ and aluminum oxide $13.04 \%$ was obtained from Sokirnica, Ukraine. Raw halloysite was obtained from the strip mine "Dunino", Intermark Company (Legnica, Poland) and modified halloysite samples is produced by the company by calcination of the raw halloysite at $650{ }^{\circ} \mathrm{C}$. Mineral reactive materials were added in amounted to $3.0 \%$ of the soil mass, and soils without materials $(0.0 \%)$ were designated as the 
control. The soil mixed with natural zeolite, raw and modified halloysite were placed in pots and incubated at constant humidity $(70 \%$ water holding capacity) fore one month.

The following parameters were determined in soil samples prior to setting up the experiment: $\mathrm{pH}$ - determined by means of the potentiometric method using an aquatic solution of $\mathrm{KCl}$ at a concentration of $1 \mathrm{M} \mathrm{KCl} \mathrm{dm}^{-3}$ with a glass electrode and a Handylab pH/LF 12 pH meter (Schott, Germany), [APHA, 1995], hydrolytic acidity (HAC) by Kappen's method, the soil samples were treated with $0.5 \mathrm{M} / \mathrm{dm}^{3}$ Ca-acetate solution adjusted to $\mathrm{pH} 8.2$ in the ratio of 1:2.5 [Klute, 1996], total exchangeable bases (TEB- $\mathrm{K}^{+}, \mathrm{Na}^{+}, \mathrm{Ca}^{2+}$, and $\mathrm{Mg}^{2+}$ ) by Kappen's method through determining individual cations after extraction from the soil with $\mathrm{CH}_{3} \mathrm{COONH}_{4}$ [Klute, 1996], cation exchange capacity (CEC) from the formula: $\mathrm{CEC}=\mathrm{HAC}$ +TEB and percentage base saturation $(\mathrm{V})$ from the formula: $\mathrm{BS}=100 \mathrm{TEB} \mathrm{CEC}^{-1}$, Organic matter was determined according to Tiurin's method, after the hot digestion of soil samples with $\mathrm{K}_{2} \mathrm{Cr}_{2} \mathrm{O}_{7}$ and $\mathrm{H}_{2} \mathrm{SO}_{4}$ in the presence of $\mathrm{Ag}_{2} \mathrm{SO}_{4}$ as a catalyst and the titration of $\mathrm{K}_{2} \mathrm{Cr}_{2} \mathrm{O}_{7}$ excess with $\mathrm{FeSO}_{4} /$ $\left(\mathrm{NH}_{4}\right)_{2} \mathrm{SO}_{4} 6 \mathrm{H}_{2} \mathrm{O}$ [Mocek and Drzymała, 2010], phosphorus and potassium content - Egner-Riehm method [Lityński et al., 1976], and magnesium content - atomic absorption spectrometry method following extraction using the Schachtschabel method [Lityński et al., 1976].

The total contents of nickel, lead, chromium, zinc and copper were determined in extracts obtained upon mineralization in nitric acid with a concentration of $1.40 \mathrm{~g} \mathrm{~cm}^{-1}$ in a MARS 5 microwave oven (CEM Corporation, USA), in HP500 teflon vessels (the parameters of the process, i.e., weight of analytical samples, volume of nitric acid, and temperature of the mineralization process complied with the US-EPA3051 Protocol). Total concentrations of the five analyzed heavy metals were determined by means of the flame atomic absorption spectrometry method on a SpectrAA 240FS spectrometer (VARIAN, Australia) in an air-acetylene flame, using a Sample Introduction Pump System.

All reagents were of analytical reagent grade. Stock solutions of metals $\left(1000 \mathrm{mg} \mathrm{L}^{-1}\right)$ were prepared from their nitrate salts and were purchased from Merck. Ultra-pure water (Millipore System, USA) $0.055 \mu \mathrm{S} \cdot \mathrm{cm}^{-1}$ resistivity was used for preparing the solutions and dilutions. All glass and polyethylene flaskware had previously been treated for 24 hours in $5 \mathrm{~mol} \cdot \mathrm{L}^{-1} \mathrm{HNO}_{3}$.
Statistical analysis was performed using the software Statistica (StatSoft, 2010). Differences of means between treatments were tested by ANOVA and comparisons of means using LSD test, at $p=0.05$. The means and standard deviations $( \pm \mathrm{SD})$ of five replications are reported. Pearson's simple correlation coefficient $(r)$ was also calculated between the heavy metal content indicated in the soil with the level of significance set at $\mathrm{P}<0.001, \mathrm{P}<0.01$ and $\mathrm{P}<0.05$.

\section{RESULTS AND DISCUSSION}

Nickel is an essential trace element in the environment and is present at varying levels in soils. The typical concentrations of this element range from 1 to $450 \mathrm{mg} \mathrm{kg}^{-1}$ in most natural soils [Bai et al., 2006], whilst in polluted soils, concentrations may reach levels as high as 200-26000 $\mathrm{mg} \mathrm{kg}^{-1}$ [Izosimova, 2005]. Soil contamination with nickel modifies the physicochemical properties of soil, while the bioavailability of Ni depends on soil properties, e.g. the proportions of nutrients, cation exchange capacity, clay content, and $\mathrm{pH}$. Li et al. [2011] proved the relationships between nickel contamination and soil properties. In the present study, the average accumulation of tested elements in Ni-contaminated soil with additives, i.e. natural zeolite, and raw and modified halloysite, was found to follow the decreasing order of $\mathrm{Ni}>\mathrm{Zn}>\mathrm{Cr}>\mathrm{Cu}>\mathrm{Pb}$. The analysis of results showed that the content of nickel in the soil was influenced by the dose of Ni-contamination as well as the addition of natural zeolite, and raw and modified halloysite (Table 1, Figure 1). In the control series (without reactive materials), the differences in the nickel of soil were positively correlated with increasing doses of nickel.

Soil samples from this experiment were characterized by nickel concentrations ranging from 2.52 to $249.10 \mathrm{mgkg}^{-1}$. Among the substances applied to neutralize nickel contamination, the application of modified halloysite was shown to be the most effective and decreased the average nickel content by $12 \%$. The application of natural zeolite to soil with the highest contamination of $\mathrm{Ni}\left(320 \mathrm{mg} \cdot \mathrm{kg}^{-1}\right)$ was the most beneficial, as it reduced the nickel content in the soil by $13 \%$. The use of low-cost and environmentally safe amendments for the immobilization of heavy metals has been investigated as a promising method for the remediation of contaminated soil. The effect of mineral reactive materials, i.e. lime [Wyszkowski 
Table 1. Effect of nickel and various mineral sorbents (NZ, RH, MH) on nickel, lead, chromium, zinc and copper concentration in soil $\left(\mathrm{mg} \cdot \mathrm{kg}^{-1}\right)$

\begin{tabular}{|c|c|c|c|c|c|c|c|c|}
\hline & \multirow{2}{*}{ Element } & \multicolumn{6}{|c|}{ Ni-concentration $\left(\mathrm{mg}^{\prime} \mathrm{kg}^{-1}\right)$} & \multirow{2}{*}{$\mathrm{LSD}_{0.05}$} \\
\hline & & 0 & 80 & 160 & 240 & 360 & $r$ & \\
\hline \multirow{4}{*}{$\mathrm{Ni}$} & Control & $3.42 \pm 0.32$ & $50.46 \pm 4.12$ & $97.40 \pm 5.33$ & $158.3 \pm 15.99$ & $249.1 \pm 19.47$ & $0.997^{* *}$ & \multirow{4}{*}{$\begin{array}{l}a-11.45 \\
b-10.41 \\
a \cdot b-19.11\end{array}$} \\
\hline & $\mathrm{NZ}$ & $2.60 \pm 0.41$ & $41.38 \pm 5.81$ & $95.92 \pm 8.98$ & $152.7 \pm 16.68$ & $216.1 \pm 26.12$ & $0.998^{* *}$ & \\
\hline & $\mathrm{RH}$ & $2.63 \pm 0.64$ & $43.66 \pm 6.32$ & $82.51 \pm 9.87$ & $153.3 \pm 18.42$ & $223.1 \pm 16.04$ & $0.995^{* *}$ & \\
\hline & $\mathrm{MH}$ & $2.52 \pm 0.48$ & $40.40 \pm 5.11$ & $87.46 \pm 8.77$ & $148.3 \pm 11.08$ & $219.0 \pm 24.77$ & $0.998^{* *}$ & \\
\hline \multirow{4}{*}{$\mathrm{Pb}$} & Control & $3.64 \pm 0.38$ & $3.73 \pm 0.52$ & $3.83 \pm 0.50$ & $4.18 \pm 0.47$ & $4.63 \pm 0.54$ & $0.996^{* *}$ & \multirow{4}{*}{$\begin{array}{l}a-0.34 \\
b-0.33 \\
a \cdot b-0.59\end{array}$} \\
\hline & $\mathrm{NZ}$ & $3.82 \pm 0.51$ & $3.89 \pm 0.58$ & $3.75 \pm 0.61$ & $3.87 \pm 0.66$ & $4.55 \pm 0.67$ & $0.759^{*}$ & \\
\hline & $\mathrm{RH}$ & $3.17 \pm 0.85$ & $3.81 \pm 0.90$ & $3.96 \pm 0.95$ & $4.90 \pm 0.94$ & $4.18 \pm 0.97$ & $0.731^{*}$ & \\
\hline & $\mathrm{MH}$ & $3.26 \pm 0.60$ & $3.32 \pm 0.79$ & $4.01 \pm 0.83$ & $4.44 \pm 0.52$ & $4.39 \pm 0.88$ & $0.916^{* *}$ & \\
\hline \multirow{4}{*}{$\mathrm{Cr}$} & Control & $9.22 \pm 0.85$ & $9.39 \pm 0.89$ & $9.94 \pm 0.84$ & $10.02 \pm 0.79$ & $10.05 \pm 0.98$ & $0.901^{* *}$ & \multirow{4}{*}{$\begin{array}{l}a-0.52 \\
b-0.56 \\
a \cdot b-1.02\end{array}$} \\
\hline & NZ & $8.17 \pm 0.87$ & $9.27 \pm 0.98$ & $9.69 \pm 0.99$ & $9.14 \pm 0.91$ & $9.47 \pm 1.02$ & $0.644^{*}$ & \\
\hline & $\mathrm{RH}$ & $8.26 \pm 1.12$ & $9.69 \pm 1.22$ & $8.87 \pm 1.14$ & $8.97 \pm 1.15$ & $8.69 \pm 1.24$ & $0.010^{*}$ & \\
\hline & $\mathrm{MH}$ & $8.09 \pm 0.97$ & $9.76 \pm 1.01$ & $9.52 \pm 1.07$ & $8.42 \pm 1.08$ & $8.05 \pm 1.12$ & $-0.313^{*}$ & \\
\hline \multirow{4}{*}{$\mathrm{Zn}$} & Control & $20.91 \pm 1.39$ & $21.01 \pm 2.03$ & $19.77 \pm 1.34$ & $19.66 \pm 1.77$ & $19.54 \pm 1.25$ & $-0.877^{* *}$ & \multirow{4}{*}{$\begin{array}{l}a-\text { n.s. } \\
b-\mathrm{n} . \mathrm{s} . \\
a \cdot b-\mathrm{n} . \mathrm{s} .\end{array}$} \\
\hline & NZ & $20.47 \pm 2.22$ & $20.44 \pm 2.46$ & $20.12 \pm 2.15$ & $19.73 \pm 1.86$ & $19.65 \pm 1.86$ & $-0.955^{* *}$ & \\
\hline & $\mathrm{RH}$ & $20.85 \pm 2.50$ & $20.88 \pm 2.52$ & $20.53 \pm 2.47$ & $20.53 \pm 2.12$ & $20.15 \pm 2.04$ & $-0.949^{* *}$ & \\
\hline & $\mathrm{MH}$ & $19.73 \pm 1.99$ & $19.81 \pm 1.28$ & $19.43 \pm 2.01$ & $19.34 \pm 2.07$ & $19.18 \pm 1.96$ & $-0.932^{* *}$ & \\
\hline \multirow{4}{*}{$\mathrm{Cu}$} & Control & $7.81 \pm 0.46$ & $7.76 \pm 0.66$ & $7.62 \pm 0.70$ & $7.51 \pm 0.72$ & $7.41 \pm 1.46$ & $-0.989^{* *}$ & \multirow{4}{*}{$\begin{array}{l}a-\text { n.s. } \\
b-1.22 \\
a \cdot b-1.09\end{array}$} \\
\hline & NZ & $7.23 \pm 0.67$ & $6.86 \pm 0.49$ & $7.09 \pm 1.22$ & $6.70 \pm 1.26$ & $5.98 \pm 0.71$ & $-0.897^{* *}$ & \\
\hline & $\mathrm{RH}$ & $6.62 \pm 0.72$ & $5.47 \pm 0.85$ & $5.57 \pm 0.97$ & $5.55 \pm 0.75$ & $5.54 \pm 0.82$ & $-0.641^{*}$ & \\
\hline & $\mathrm{MH}$ & $5.61 \pm 0.69$ & $5.41 \pm 0.61$ & $5.36 \pm 0.59$ & $5.36 \pm 0.58$ & $5.00 \pm 0.91$ & $-0.938^{* *}$ & \\
\hline
\end{tabular}

Mean values for five samples ( \pm standard deviation) are shown. LSD for: $a$ - nickel dose, $b-$ type of neutralizing substance, $a b$ - interaction; n.s. - non-significant; $\mathrm{r}$ - correlation coefficient, significant for: ${ }^{* *}-\mathrm{P}<0.01$, ${ }^{*}$ - $\mathrm{P}<0.05$; NZ - natural zeolite; $\mathrm{RH}$ - raw halloysite; $\mathrm{MH}$ - modified halloysite

and Radziemska, 2009], halloysite [Radziemska et al., 2014], zeolite [Putwattana et al., 2015] and diatomite [Ye et al., 2015] on soils polluted with heavy metals has been investigated by several authors. Halloysite $\left(\mathrm{Al}_{2} \mathrm{Si}_{2} \mathrm{O}_{5}(\mathrm{OH})_{4} \mathrm{H}_{2} \mathrm{O}\right)$ is a lowcost, environment-friendly and natural nanostructured mineral exhibiting tubular morphology; dehydrated halloysite- $(7 \AA)$ is characterized by a brownish color due to the presence of $\mathrm{Fe}$ and $\mathrm{Ti}$ in its structure, as well as the co-existence of $\mathrm{Fe}$ and Ti-oxide minerals [Matusik and Wścisło, 2014]. In comparison with other reactive materials, halloysite is more abundant and much cheaper, and has been used as a candidate adsorbent due to its tubular structure. Complexation, ion exchange, precipitation, and adsorption are the major mechanisms involved in the transition of soluble forms of heavy metals to geochemically stable solid phases, thus reducing the heavy metal available for uptake by plants in soils [Cao et al., 2008].

Lead is commonly encountered in contaminated sites worldwide, and several studies have demonstrated direct correlations between lead in soil and its levels in blood [Li et al., 2015]. Ur- ban areas are characterized by higher contamination with this element, while road transport has been a major source for lead emissions compared to other anthropogenic factors [Domańska et al., 2015]. In the presented study, lead content in soil was significantly influenced by: the contamination of soil by nickel (dose) and neutralizing substances in the form of natural zeolite as well as raw and modified halloysite (Table 1, Figure 1). Concentration of lead in the tested soil samples ranged from 3.17 to $4.90 \mathrm{mg} \mathrm{kg}{ }^{-1}$ of soil. In the control treatments (without mineral additives), the highest dose of nickel caused an increase in the content of lead of up to $21 \%$ as compared to the control. The highest reduction of lead content was observed in the soil from pots to which 80 and $160 \mathrm{mg}$ of nickel had been applied per $1 \mathrm{~kg}$ of soil after modified halloysite had been added. An analogical situation was observed in the case of adding natural zeolite and raw halloysite (RH), although their influence was weaker. In a study by Ye et al. [2015], soil contaminated with heavy metals, after being treated with $5.0 \%$ modified diatomite for 90 days, showed $69.7 \%$ reductions 

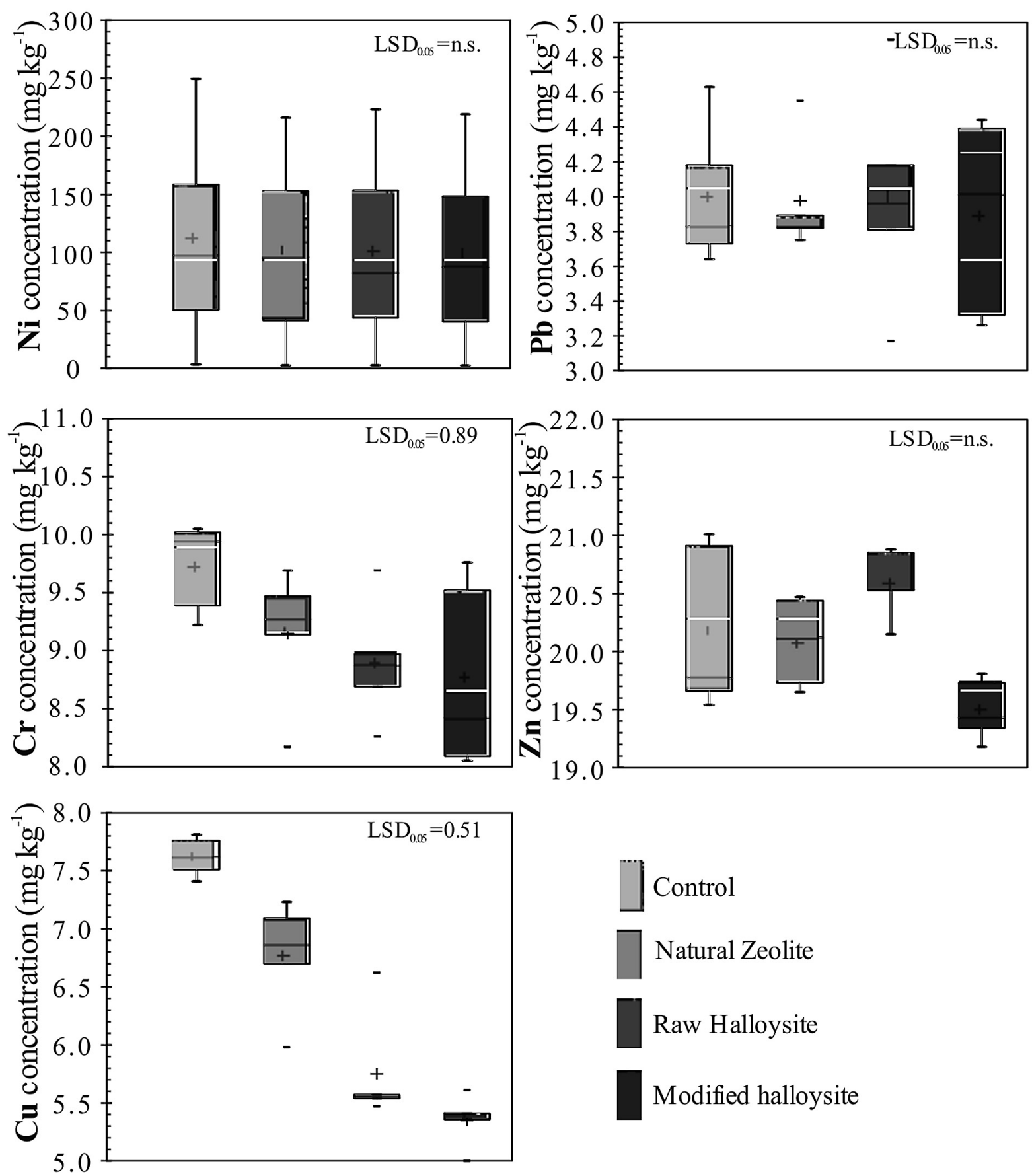

Figure 1. Content of trace elements in soil after plants harvest. Boxplots showing the median, quartiles, and minimum and maximum values of the heavy metals concentrations in soil

in lead concentrations upon $0.01 \mathrm{M} \mathrm{CaCl}_{2}$ extraction. Kumpiene [2010] reported metal immobilization when adding bentonite to soil, which is able to limit metal leaching through ion exchange and chemisorption. On the other hand, the coremediation of $\mathrm{Pb}$-polluted garden soil by zeolite and humic acids limited the availability of lead in the soil as well as enhancing the validity of phytoremediation [Shi et al., 2008].

Table 2 indicates that the application of mineral sorbents and increasing Ni-concentrations influenced the chromium content of tested soil. Excessive deposits of chromium in soils may lead to elevated heavy metal uptake by crops, affecting the quality and safety of foods [Maleki et al., 2015]. In the present study, the concentrations of chromium ranged from 8.05 to $10.05 \mathrm{mg} \mathrm{kg}^{-1}$ of soil. In the control series (no additives), the differences in chromium content were positively correlated with increasing doses of the abovementioned element. Soil contamination at 360 $\mathrm{mg} \mathrm{Ni} \cdot \mathrm{kg}^{-1}$ soil led to the highest increase in $\mathrm{Cr}$ 
Table 2. Simple linear correlation coefficient (r) between the content of heavy metals in soil

\begin{tabular}{|c|c|c|c|c|}
\hline \multicolumn{5}{|c|}{ Control } \\
\hline Element & $\mathrm{Ni}$ & $\mathrm{Pb}$ & $\mathrm{Zn}$ & $\mathrm{Cr}$ \\
\hline $\mathrm{Pb}$ & $0.982^{* *}$ & & & \\
\hline $\mathrm{Zn}$ & $-0.857^{*}$ & $-0.782^{*}$ & & \\
\hline $\mathrm{Cr}$ & $0.875^{*}$ & $0.780^{*}$ & $-0.979^{* * *}$ & \\
\hline $\mathrm{Cu}$ & $-0.984^{* * * *}$ & $-0.950^{* *}$ & $0.931^{* *}$ & $-0.936^{* *}$ \\
\hline \multicolumn{5}{|c|}{ Natural zeolite (NZ) } \\
\hline Element & $\mathrm{Ni}$ & $\mathrm{Pb}$ & $\mathrm{Zn}$ & $\mathrm{Cr}$ \\
\hline $\mathrm{Pb}$ & $0.739^{*}$ & & & \\
\hline $\mathrm{Zn}$ & $-0.972^{* * *}$ & $-0.621^{*}$ & & \\
\hline $\mathrm{Cr}$ & $0.615^{*}$ & $0.269^{*}$ & $-0.502^{*}$ & \\
\hline $\mathrm{Cu}$ & $-0.881^{* *}$ & $-0.942^{* *}$ & $0.784^{*}$ & $-0.456^{*}$ \\
\hline \multicolumn{5}{|c|}{ Raw halloysite $(\mathrm{RH})$} \\
\hline Element & $\mathrm{Ni}$ & $\mathrm{Pb}$ & $\mathrm{Zn}$ & $\mathrm{Cr}$ \\
\hline $\mathrm{Pb}$ & $0.747^{*}$ & & & \\
\hline $\mathrm{Zn}$ & $-0.938^{* *}$ & $-0.540^{*}$ & & \\
\hline $\mathrm{Cr}$ & $-0.021^{*}$ & $0.313^{*}$ & $0.247^{*}$ & \\
\hline $\mathrm{Cu}$ & $-0.597^{*}$ & $-0.721^{*}$ & $0.499^{*}$ & $-0.730^{*}$ \\
\hline \multicolumn{5}{|c|}{ Modified halloysite $(\mathrm{MH})$} \\
\hline Element & $\mathrm{Ni}$ & $\mathrm{Pb}$ & $\mathrm{Zn}$ & $\mathrm{Cr}$ \\
\hline $\mathrm{Pb}$ & $0.920^{* *}$ & & & \\
\hline $\mathrm{Zn}$ & $-0.938^{* *}$ & $-0.960^{*}$ & & \\
\hline $\mathrm{Cr}$ & $-0.374^{*}$ & $-0.324^{*}$ & $0.445^{*}$ & \\
\hline $\mathrm{Cu}$ & $-0.923^{* *}$ & $-0.728^{*}$ & $0.802^{*}$ & $0.195^{*}$ \\
\hline
\end{tabular}

Correlation is significant at ${ }^{* * *} p<0.001 ;{ }^{* *} p<0.01 ;{ }^{*} p<0.05$ level.

content in the soil. Among the substances applied, the strongest effects were caused by natural zeolite, which significantly reduced the average content of chromium in Ni-contaminated soil. Zeolite can lead to the immobilization of metals in many ways, e.g. the increase in alkalinity promotes heavy metal sorption [Querol et al., 2006]. In connection with the above, in research carried out by Herwijnen et al. [2007], zeolite-amended composts were found to be more effective than un-amended ones in the remediation of heavy metal polluted soils in the leaching experiment.

The present study indicates a strong relationship between the application of neutralizing substances and increasing nickel concentrations of soil on the zinc content in soil (Table 1, Figure 1). Concentrations of zinc ranged from 19.18 to 21.01 $\mathrm{mg} \mathrm{kg}^{-1}$ of soil. In general, applying nickel to soil contributed to decreased levels of zinc in soil in the control series - without neutralizing additives. An exception to this was the soil with the highest dose $\left(80 \mathrm{mg} \cdot \mathrm{kg}^{-1}\right.$ soil) of nickel. In the treatments without mineral additives, the highest dose of nickel caused a decrease of $7 \%$ in the content of zinc as compared to the control. LiU et al. [2009] showed that easily mobilized $\mathrm{Zn}$ can be trans- ferred to deeper layers of soil. By introducing substances that are capable of increasing the sorption capacity of soil, such as zeolites, halloysites, or other compounds which exhibit sorption properties, the amount of absorbable forms of heavy metals in the soil can be decreased [Radziemska et al., 2014]. The highest reduction of $\mathrm{Zn}$ content was observed in soil from pots to which 80 and $240 \mathrm{mg}$ of $\mathrm{Ni}$ were used per $1 \mathrm{~kg}$ of soil along with the addition of modified halloysite.

Copper content in soil was affected by the dose of nickel and by the type of the reactive materials applied (Table 1, Figure 1). In the present studies, the concentration of copper ranged from 5.36 to $7.81 \mathrm{mg} \mathrm{kg}{ }^{-1}$ of soil. In general, applying nickel to soil contributed to reduced levels of copper in the soil as compared to the control series - without natural zeolite, raw and modified halloysite. In the series lacking neutralizing additives, Ni-contamination significantly reduced the content of copper in the soil. Modified halloysite added to objects containing increased doses of nickel reduced the average amount of copper in soil by $30 \%$ when compared soil to which neutralizing substances had not been added. According to Terzano et al. [2005], zeolite synthesized 
from fly ash can be effective in reducing copper mobility and availability. The present research reveals that the application of natural zeolite to soil with the highest dose $\left(360 \mathrm{mg} \cdot \mathrm{kg}^{-1}\right.$ soil $)$ of $\mathrm{Ni}$ reduced the amount of copper in the soil by $19 \%$.

Correlation testing was carried out to evaluate the relationship between heavy metal content and various $\mathrm{Ni}$-doses in soils amended with different mineral sorbent treatments (Table 2). The simple linear correlation coefficient indicated significant correlations between heavy metals in soil and increasing nickel contamination. In the control series (no additives), the highest values of significant correlation coefficients occurred between the contents of nickel and lead, as well as copper and zinc $(r=0.982, r=0.931)$. Significant negative correlations were found between the contents of nickel and zinc in soil with natural zeolite $(r=-0.938)$ and zinc and copper $(r=-0.923)$ with modified halloysite. Moreover, natural zeolite in soil with nickel was also significantly negatively correlated with the content of zinc $(r=-0.972)$ and copper $(r=-0.881)$.

\section{CONCLUSIONS}

The combination of the phytoremediation process with the modification of the physicochemical properties of soil by introducing mineral reactive materials like zeolites or halloysites, may significantly shorten the time required to complete the entire remediation process. The present experimental results indicate that NZ, RH and $\mathrm{MH}$ immobilization of heavy metals was an effective way of remediating soils contaminated with heavy metals.

The content of $\mathrm{Ni}, \mathrm{Pb}, \mathrm{Cr}, \mathrm{Cu}$ and $\mathrm{Zn}$ in soil depended on the dose of $\mathrm{Ni}$, as well as the addition of natural zeolite, and raw and modified halloysite. The average accumulation of heavy metals in Ni-contaminated soil was found to follow the decreasing order of $\mathrm{Ni}>\mathrm{Zn}>\mathrm{Cr}>\mathrm{Cu}>\mathrm{Pb}$. The mostly distinct changes were confirmed in the case of $\mathrm{Zn}$ and $\mathrm{Cu}$, the soil contents of which were significantly decreased by the highest doses of nickel. Contamination at $320 \mathrm{mg} \mathrm{Ni} \mathrm{kg}^{-1}$ of soil led to the highest increase in $\mathrm{Ni}, \mathrm{Pb}$ and $\mathrm{Cr}$ in the soil. The highest reduction of $\mathrm{Pb}$ content was observed in soil from pots to which 80 and 160 $\mathrm{mg} \mathrm{kg}{ }^{-1}$ of $\mathrm{Ni}$, containing an addition of modified halloysite. Soil contamination at $360 \mathrm{mg} \mathrm{Ni} \cdot \mathrm{kg}^{-1}$ soil led to the highest increase of Cr. The stron- gest effects on this element were caused by natural zeolite, which reduced its content. In the treatments without mineral additives, the highest dose of nickel caused a decrease in the content of $\mathrm{Zn}$ of $7 \%$. Modified halloysite reduced the average amount of $\mathrm{Cu}$ in soil by $30 \%$.

\section{REFERENCES}

1. USEPA, Exposure Factors Handbook. US Environmental Protection Agency, Washington, DC 1997, (EPA/600/P-95/002F a-c).

2. Sas W., Głuchowski A., Radziemska M., Dzięcioł J., Szymański A. 2015. Environmental and geotechnical assessment of the steel slags as a material for road structure. Materials, 8, 4857-4875.

3. Radziemska M., Fronczyk J. 2015. Level and contamination assessment of soil along an expressway in an ecologically valuable area, central Poland. International Journal of Environmental Research and Public Health, 12, 13372-13387.

4. Tuovinen H., Pohjolainen E.M., Lempinen J., Vesterbacka D., Read D., Solatie D., Lehto J. 2016. Behaviour of radionuclides during microbiallyinduced mining of nickel at Talvivaara, Eastern Finland. Journal of Environmental Radioactivity, 151, 105-113.

5. Gupta D.K., Chatterjee S., Datta S., Veer V., Walther C. 2014. Role of phosphate fertilizers in heavy metal uptake and detoxification of toxic metals. Chemosphere, 108, 134-144.

6. Huang C.L., Vause J., Ma H.W., Li Y., Yu C.P. 2014. Substance flow analysis for nickel in mainland China in 2009. Journal of Cleaner Production, 84, 450-458.

7. Kuziemska B., Kalembasa S., Wieremiej W. 2014. Distribution of nickel in fractions extracted with the BCR procedure from nickel-contaminated soil. Journal of Elementology, 19, 3, 697-708.

8. Wyszkowski M., Radziemska M. 2009. Effect of some substances on the content of selected components in soils contaminated with chromium. Ecological Chemistry and Engineering A, 18, 11, 1497-1504.

9. Belchinskaja L.I, Khodosova N.A., Stelnikova O.Y. 2009. Use of natural and modified nanoporous sorbents for clearing of air medium and sewage. Annals of Warsaw University of Life Sciences - SGGW, Forestry and Wood Technology, 68, 32-36.

10. Fronczyk J., Radziemska M., Jeznach J. 2014. Evaluation of diatomite and chalcedonite as reactive materials protecting groundwater In traffic infrastructure. Fresenius Environmental Bulletin, 23, 12b, 3331-3339. 
11. Fronczyk J., Radziemska M., Mazur Z. 2015. Copper removal from contaminated groundwater using natural and engineered limestone sand in permeable reactive barriers. Fresenius Environmental Bulletin, 24, 1a, 228-234.

12. Guimarães L., Enyashin A.N., Seifert G., Duarte H.A. 2010. Structural, electronic, and mechanical properties of single-walled halloysite nanotube models. Journal of Physical Chemistry C, 114, 11358-11363.

13. Cavallaro G., Gianguzza A., Lazzara G., Milioto S., Piazzese D. 2013. Alginate gel beads filled with halloysite nanotubes. Applied Clay Science, 72, 132-137.

14. Liu M., Wu C., Jiao Y., Xiong S., Zhou C. 2013. Chitosan-halloysite nanotubes nanocomposite scaffolds for tissue engineering. Journal of materials chemistry, Materials for biology and medicine, 1, 2078-2089.

15. Radziemska M., Mazur Z., Jeznach J. 2013. Influence of applying halloysite and zeolite to soil contaminated with nickel on the content of selected elements in maize (Zea mays L.). Chemical Engineering Transactions, 32, 301-306.

16. Radziemska M., Mazur Z., Fronczyk J., Jeznach J. 2014. Effect of zeolite and halloysite on accumulation of trace elements in maize (Zea Mays L.) in nickel contaminated soil. Fresenius Environmental Bulletin, 23, 12a, 3140-3146.

17. Dong F., Wang J.A., Wang Y., Ren S. 2012. Synthesis and humidity controlling properties of halloysite/poly (sodium acrylate-acrylamide) composite. Journal of Materials Chemistry, 22, 11093-11100.

18. Pimraksa K., Chindaprasirt P., Huanjit T., Tang C., Sato T. 2013. Cement mortars hybridized with zeolite and zeolite like materials made of lignite bottom ash for heavy metal encapsulation. Journal of Cleaner Production, 41, 31-41.

19. Shi W., Shao H., Li H., Shao M., Du S. 2009. Progress in the remediation of hazardous heavy metalpolluted soils by natural zeolite. Journal of Hazardous Materials, 170, 1-6.

20. Silva B., Figueiredo H., Quintelas C., Neves I.C., Tavares T. 2008. Zeolites as supports for biorecovery od hexavalent chromium and trivalent chromium. Microporous and Mesoporous Materials, 116, 550-560.

21. APHA (American Public Health Association), Standard Methods for the Examination of Water and Wastewater. APHA, Washington, DC, 1995.

22. Klute A., Methods of soil analysis. Madison: American Society of Agronomy. Agronomy Monograph 9, 1996.

23. Mocek A., Drzymała S., Genesis. Analysis and Soil Classification. Poznan University of Life Sciences (in Polish) 2010.
24. Lityński T., Jurkowska H., Gorlach E. 1976. Chemical and agriculture analysis. PWN, Warszawa, 129-132 (in Polish).

25. Bai C., Reilly C.C., Wood B.W. 2006. Nickel deficiency disrupts metabolism of ureides, amino acids, and organic acids of young pecan foliage. Plant Physiology, 140, 433-443.

26. Izosimova A. 2005. Modelling the interaction between calcium and nickel in the soil-plant system. Germany, Published by Die Deutsche Bibliothek, 288, 99.

27. Li B., Zhang H., Ma Y., McLaughlin M.J. 2011. Influences of soil properties and leaching on nickel toxicity to barley root elongation. Ecotoxicology and Environmental Safety, 74, 459-466.

28. Wyszkowski M., Radziemska M. 2009. The effect of chromium content in soil on the concentration of some mineral elements in plants. Fresenius Environmental Bulletin, 18, 7, 1039-1045.

29. Putwattana N., Kruatrachue M., Kumsopac A., Pokethitiyook P. 2015. Evaluation of organic and inorganic amendments on maize growth and uptake of $\mathrm{Cd}$ and $\mathrm{Zn}$ from contaminated paddy soils. International Journal of Phytoremediation, 17, 2, 165-174.

30. Ye X., Kang S., Wang H., Li H., Zhang Y., Wang G., Zhao H. 2015. Modified natural diatomite and its enhanced immobilization of lead, copper and cadmium in simulated contaminated soils. Journal of Hazardous Materials, 289, 210-218.

31. Matusik J., Wścisło A. 2014. Enhanced heavy metal adsorption on functionalized nanotubular halloysite interlayer grafted with aminoalcohols. Applied Clay Science, 100, 50-59.

32. Cao X., Dermatas D., Xu X., Shen G. 2008. Immobilization of lead in shooting range soils by means of cement, quicklime, and phosphate amendments. Environmental Science and Pollution Research, $15,120-127$.

33. Li P., Lin C., Cheng H., Duan X., Lei K. 2015. Contamination and health risks of soil heavy metals around a lead/zinc smelter in southwestern China. Ecotoxicology and Environmental Safety, 113, 391-399.

34. Domańska J., Badora A., Filipek T. 2015. The sensitivity of Brassica napus ssp. oleifera to cadmium $(\mathrm{Cd})$ and lead $(\mathrm{Pb})$ contamination at different $\mathrm{pH}$ of mineral and organic soils. Journal of Elementology, 20, 1, 59-71.

35. Kumpiene J., Trace element immobilization in soil using amendments. In: Hooda, P.S. (Ed.), Trace Element in Soils. Wiley-Blackwell, Chichester, UK 2010, pp. 353-380.

36. Shi W.Y., Shao H.B., Li H., Shao M.A., Du S. 2008. Co-remediation of the lead-polluted garden soil by exogenous natural zeolite and humic acids. Journal of Hazardous Materials, 167, 136-140. 
37. Maleki A., Hayati B., Naghizadeh M., Joo S.W. 2015. Adsorption of hexavalent chromium by metal organic frameworks from aqueous solution. Journal of Industrial and Engineering Chemistry, 28, 211-216.

38. Querol X., Alastuey A., Moreno N., Alvarez-Ayuso E., Garcia-Sanchez A., Cama J. et al. 2006. Immobilization of heavy metals in polluted soils by the addition of zeolitic material synthesized from coal fly ash. Chemosphere, 171, 171-180.

39. Herwijnen R., Hutchings T.R., Ai-Tabbaa A., Moffat A.J., Johns M.L., Ouki S.K. 2007. Remediation of metal contaminated soil with mineral-amended composts. Environmental Pollution, 150, 347-354.

40. Liu H., Chen L., Ai Y., Yang X., Yu Y., Zuo Y., Fu G. 2009. Heavy metal contamination in soil alongside mountain railway in Sichuan, China. Environmental Monitoring Assessment, 152, 25-33.

41. Terzano R., Spagnuolo M., Medici L., Vekemans B., Vincze L., Janssens K., Ruggiero P. 2005. Copper stabilization by zeolite synthesis in polluted soils treated with coal fly ash. Environmental Science and Technology, 39, 6280-6287. 